\title{
Petroleum systems of the Taoudeni Basin, West Africa
}

\author{
Huang Zhilong*, Zhao Baoshun, Jiang Qingchun, Wang Songpo and Liu Bo
}

Key Laboratory for Hydrocarbon Accumulation, China University of Petroleum, Ministry of Education, Beijing 102249, China

\begin{abstract}
The Taoudeni Basin is a typical steady intracratonic basin. Based on the distribution of effective source rocks in the Taoudeni Basin, combined with the structure characteristics of the basin and the distribution characteristics of reservoir beds, two petroleum systems are recognized in the basin: the infra-Cambrian petroleum system and the Silurian petroleum system. Structural uplift and timing of petroleum generation controlled the timing of petroleum charging and preservation of hydrocarbon accumulations. Maturity, evolution history, and distribution of effective source rocks controlled hydrocarbon richness. The geological key factors and geological processes controlled the type of hydrocarbon accumulations.
\end{abstract}

Key words: Taoudeni Basin, source-reservoir-cap rock assemblage, petroleum system, integrated analysis

\section{Characteristics of geology}

\subsection{Stratigraphy and Depositional Environment}

The Taoudeni Basin is a typical steady intracratonic basin in Mauritania and Mali, west Africa (Macgregor, 1998) (Fig.1). Its sediment fill was dominated by marine clastic rocks which consisted of sandstone, siltstone and claystone. In addition, subordinate carbonates were also deposited and were mainly composed of dolomitic limestone and thickly bedded stromatolite.

Three depositional cycles were developed in the Taoudeni Basin (Mann et al, 2003; Makhous et al, 1997). They are infra-Cambrian sandstone-carbonate (including limestone and stromatolite/dolomite) depositional cycle, CambrianOrdovician sandstone-claystone depositional cycle and Devonian-Carboniferous transgressive claystone and carbonate depositional cycle.

Two main depocenters were present in the Taoudeni Basin during the infra-Cambrian time (Tong and Guan, 2002; USGS, 2000). They are the Makteir depocenter in the west and the Taoudeni depocenter in the east. Subsidence began from the infra-Cambrian time and a few hundred meters of thick sandstones were deposited. In the Middle infraCambrian time, the sedimentary environment evolved into marine setting, which led to the deposition of a suit of very thick stromatolite and interbedded claystones (mudstone and shale). The stromatolite was composed of dolomitic limestone. The claystones constituted source rocks. In the late infra-Cambrian time, water became shallower with tectonic uplifting and deposited rocks were subject to weathering.

*Corresponding author. email: huang5288@163.com Received November 13, 2006

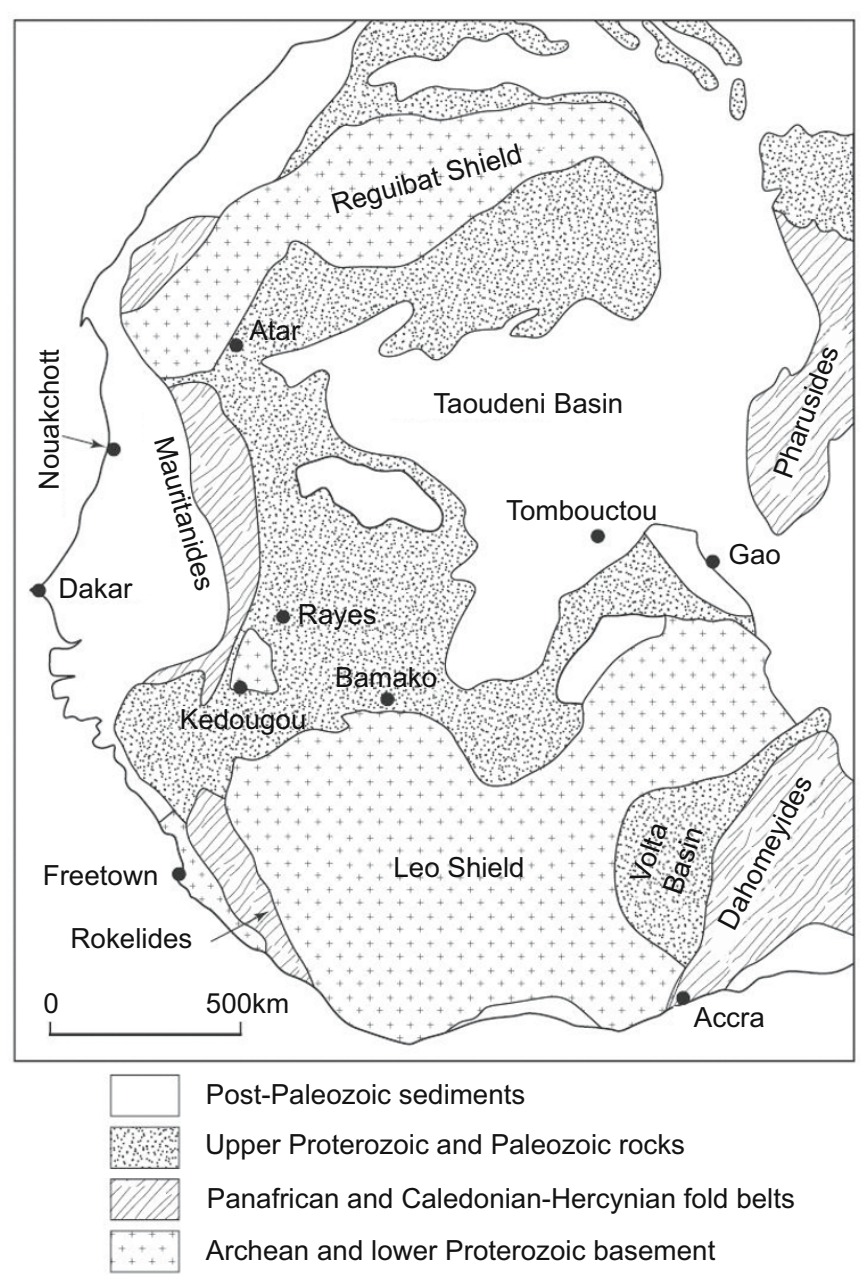

Fig. 1 Location map of the Taoudeni Basin 
Then the basin subsided again to receive sediments. The Upper Cambrian overlies the infra-Cambrian stromatolite unconformably. Subsequent frequent marine transgression and regression led to the deposition of a suit of interbedded sandstone and shale sequences.

\subsection{Source rock}

The Taoudeni Basin is a typical steady intracratonic basin. Source rocks have similar characteristics, but their thickness varies from $20 \mathrm{~m}$ to $500 \mathrm{~m}$. The organic matter abundance of source rocks in different stratigraphic intervals varies significantly. The kerogens are pro-sapropelic type II.

So far, there is little well data in the Taoudeni Basin. The Abolag-1 and the Ouasa-1 wells are the only wells drilled in the Mauritanian sector of the basin. The features shown by just two wells cannot truly reflect source rock distribution within the entire Taoudeni Basin. Source rock intervals in the two wells consist of red mudstone, dust-brown mudstone and black mudstone. There are two periods for the development of large-scale depressions in the Taoudeni Basin. They are the infra-Cambrian depression and the Paleozoic depression. During the infra-Cambrian, two depressions were developed: the Maqteir depression (or west depression) in the west and Taoudeni depression (or east depression) in the east. The Paleozoic depressions were superimposed upon the infraCambrian structural configuration.

Infra-Cambrian source rocks are mainly distributed in the Maqteir and Taoudeni depressions. The Taoudeni depression is located in Mali. It covers a large area and was buried to a great depth. The Maqteir depression is located in Mauritania and it covers an area much smaller than the Taoudeni depression. Paleozoic source rocks are mainly confined to the Paleozoic depressions.

\subsection{Reservoir Rock}

Integration of cores, cuttings, wireline logs and oil/gas testing data from the Ouasa- 1 and the Abolag-1 wells indicates that six sets of reservoir beds are present in the Taoudeni Basin (Table 1): Lower infra-Cambrian sandstone, Middle infra-Cambrian paleo-karsted and fractured limestone, Middle/ Upper infra-Cambrian sandstone, Ordovician sandstone, and basal Devonian sandstone (Figs. 2, 3, 4 and 5).

1) Lower infra-Cambrian reservoir beds: They mainly occur in the upper part of the lower infra-Cambrian. These reservoir beds were composed of sandstones with an average thickness of more than $60 \mathrm{~m}$. Due to great burial depth, old age and strong diagenesis, petrophysical properties are generally poor. The CNL porosity is almost 0 and the permeability is very low. It is difficult for them to be effective reservoir beds.

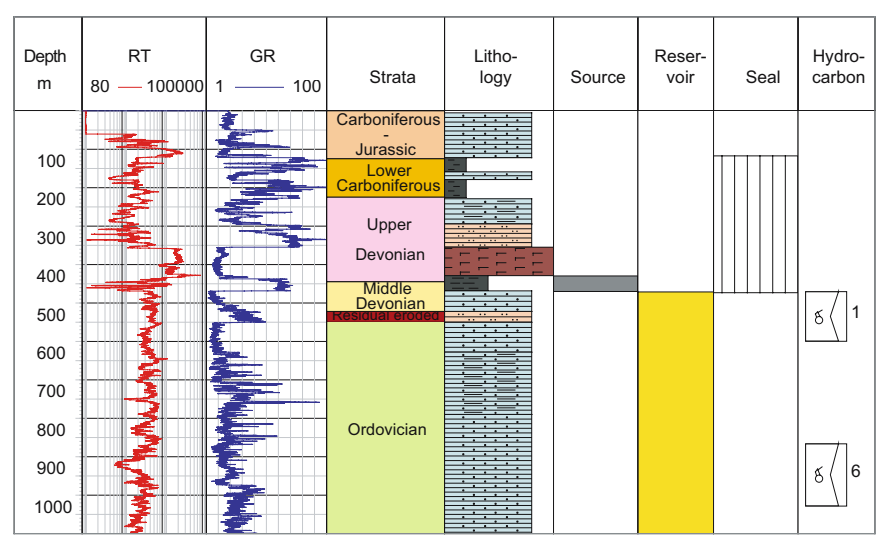

Fig. 2 Profile showing source-reservoir-cap rock assemblage for Ouasa-1 well

Table 1 Reservoir rocks in the two wells in western Taoudeni Basin

\begin{tabular}{|c|c|c|c|c|c|}
\hline \multicolumn{3}{|c|}{ Well Abolag-1 } & \multicolumn{3}{|c|}{ Well Ouasa-1 } \\
\hline Reservoir bed & $\begin{array}{c}\text { Thickness } \\
\mathrm{m}\end{array}$ & Lithology & Reservoir bed & $\begin{array}{c}\text { Thickness } \\
\mathrm{m}\end{array}$ & Lithology \\
\hline Basal Devonian & 40 & Sandstone & Basal Devonian & 53.2 & Sandstone \\
\hline Ordovician & 550 & sandstone & Ordovician & 558 & Sandstone \\
\hline $\begin{array}{l}\text { Middle and up- } \\
\text { per upper infra- } \\
\text { Cambrian }\end{array}$ & 151 & sandstone & $\begin{array}{c}\text { Upper upper } \\
\text { infra-Cambrian }\end{array}$ & 170.8 & $\begin{array}{c}\text { Tight } \\
\text { sandstone }\end{array}$ \\
\hline $\begin{array}{c}\text { Basal upper } \\
\text { infra-Cambrian }\end{array}$ & 76 & Tight sandstone & $\begin{array}{l}\text { Middle upper } \\
\text { infra-Cambrian }\end{array}$ & 133.2 & $\begin{array}{c}\text { Tight } \\
\text { sandstone }\end{array}$ \\
\hline $\begin{array}{l}\text { Middle infra- } \\
\text { Cambrian } \\
\text { Karsted and } \\
\text { fractured lime- } \\
\text { stone }\end{array}$ & 190 & Carbonate rock & $\begin{array}{c}\text { Basal upper } \\
\text { infra-Cambrian }\end{array}$ & 144.4 & $\begin{array}{c}\text { Tight } \\
\text { sandstone }\end{array}$ \\
\hline $\begin{array}{l}\text { Lower infra- } \\
\text { Cambrian }\end{array}$ & $>60$ & $\begin{array}{l}\text { Tight quartz } \\
\text { sandstone }\end{array}$ & $\begin{array}{l}\text { Middle infra- } \\
\text { Cambrian }\end{array}$ & & \\
\hline
\end{tabular}




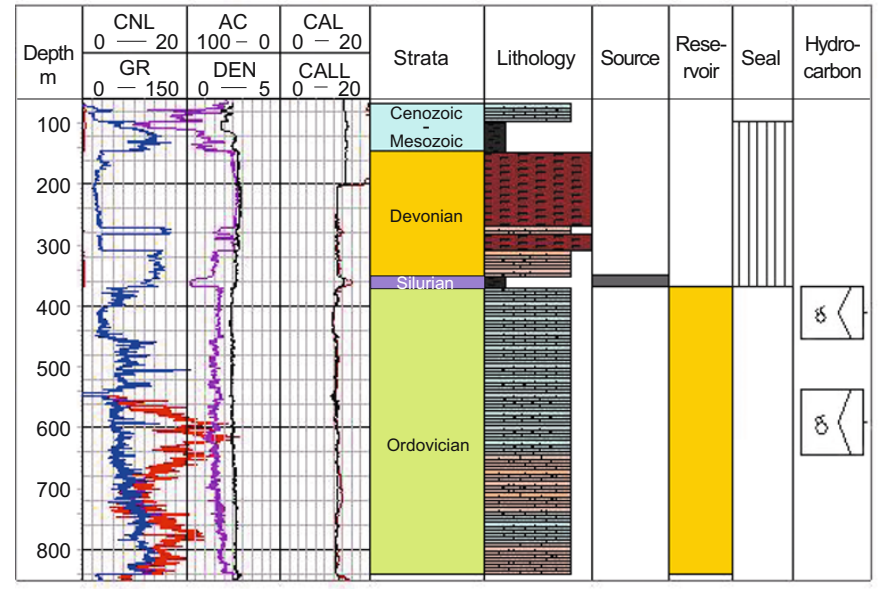

Fig. 3 Profile showing source-reservoir-cap rock assemblage for Abolag-1 well

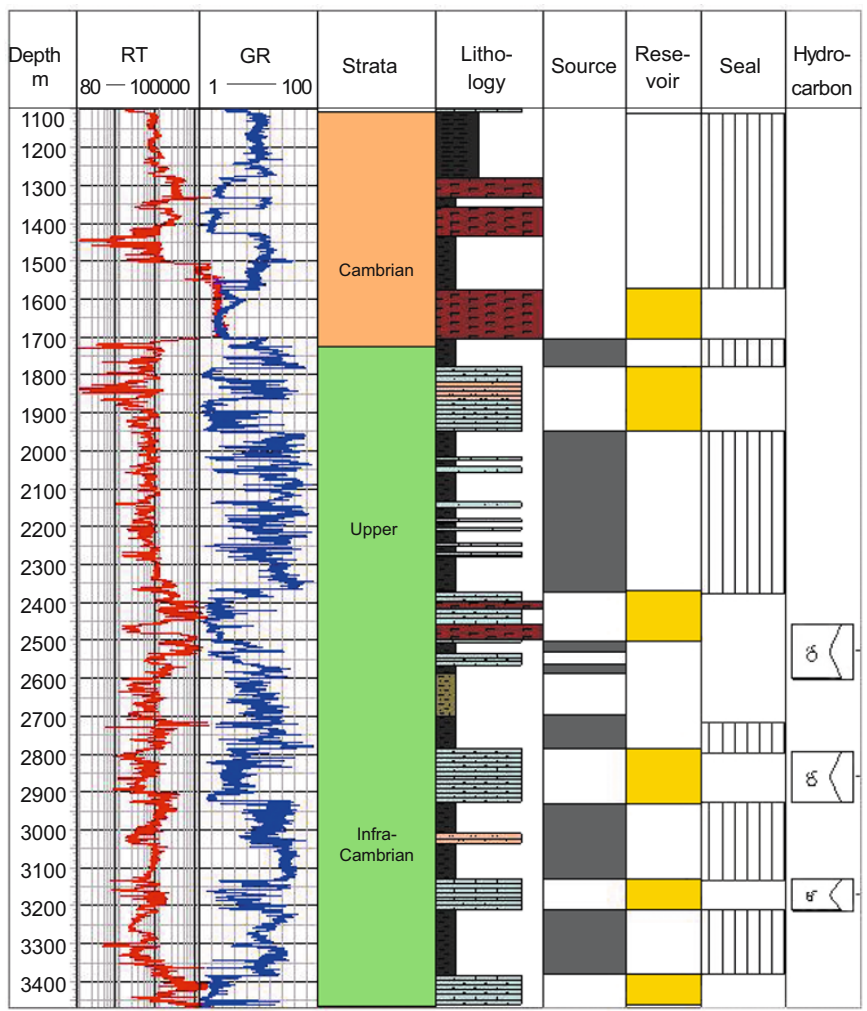

Fig. 4 Profile showing source-reservoir-cap rock assemblage for Ouasa-1 well

2) Middle infra-Cambrian karsted and fractured limestones: The total thickness for this interval can reach 190 meters. During its deposition, there was no input of detrital clasts. Stromatolite was developed in a typical shallow epicontinental sea and tidal flat environment. There were active oil and gas shows during drilling. Reservoir beds were composed of stromatolite. The porosity type varies greatly. Intra-particle and dissolved pores are most developed. There is little primary porosity whereas secondary porosity is well developed, so could be filled completely in the later diagenesis There is a weathered surface on the top of the interval where karsting and dissolution took place, which led

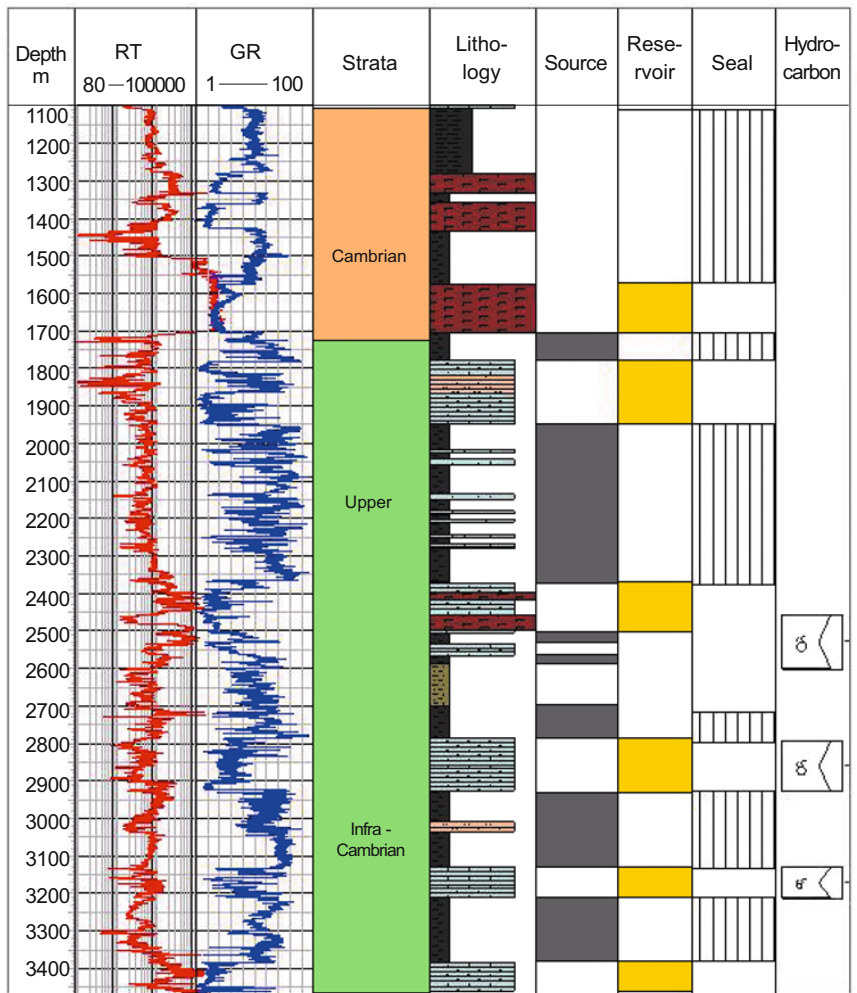

Fig. 5 Profile showing source-reservoir-cap rock assemblage for Abolag-1 well

to the development of dissolution porosities. As a result, the stromatolite could become fine oil and gas reservoir beds. Due to compression and compaction, stromatolite could be easily fractured to become fractured reservoir beds.

3) Basal upper infra-Cambrian reservoirs: In the Ouasa-1 and Abolag-1 wells, the reservoir interval constitutes an $80 \mathrm{~m}$ thick sandstone sequence in the basal Upper InfraCambrian. The porosity is very low. The reservoir beds are dominated by tight sandstones.

4) Middle-upper upper infra-Cambrian reservoirs: Sandstone reservoir beds with a thickness of up to $100 \mathrm{~m}$ are distributed in the middle and upper parts of the Upper InfraCambrian in the Ouasa-1 and Abolag-1 wells. Their average porosity is $8-15 \%$.

5) Ordovician sandstones: The Ordovician is dominated by sandstones (Chen et al, 2007). Its thickness is between $400-500 \mathrm{~m}$. The sandy sequence is a main reservoir interval in the Taoudeni Basin, with oil and gas shows. The porosity is approximately $7-15 \%$ and can reach as high as 18 to $22 \%$ in some intervals. The permeability is $0.2-1 \mathrm{md}$.

6) Basal Devonian reservoirs: The Devonian overlies the older sequences unconformably. Over the unconformity, tillite and sandstone were developed. The basal Devonian in the Ouasa-1 well is a set of sandstone reservoir beds and is a suit of brittle fine to medium grained sandstone. The average porosity is $10 \%$.

\subsection{Cap rocks}

Cap rocks are developed in various stratigraphic intervals in the Ouasa-1 and Abolag-1 wells. They are dominated by 
mudstones and shale.

During the Middle infra-Cambrian, depositional environment was neritic and mudstone was deposited. The tight calcareous mudstone thickness is up to $200 \mathrm{~m}$. Sealing capacity of this set of mudstone is very good.

During the Late infra-Cambrian, sea level changed frequently. There were numerous cycles of sand-mudstone sequences. Mudstone thickness varies for muddy intervals in different cycles. Individual mudstone layers are $10 \mathrm{~m}-20 \mathrm{~m}$ thick and some of these can reach $50 \mathrm{~m}-60 \mathrm{~m}$. The mudstones are gray and brown in color and normally interbedded with sandstones. They have experienced intensive diagenesis and have good seal ability.

During the Cambrian, two large scale sand-mudstone cycles were developed. The mudstone is gray and fairly thick. Cambrian mudstones are approximately 190m.thick in the Abolag-1 well and $360 \mathrm{~m}$ in the Ouasa-1 well. They have good sealing capacity.

During the Silurian, two periods of deposition hiatus occurred. But the Silurian as a whole is a transgressive sequence. Thick mudstone was developed in the Taoudeni depression. The Silurian mudstone can act as a good seal for the Ordovician reservoirs.

\subsection{Types of source-reservoir-cap rock assemblage}

In the basin, three types of source-reservoir-cap rock assemblages, in situ source and reservoir, lower source \& upper reservoir, and upper source \& lower reservoir are developed. They are illustrated in Fig. 6.

\section{Petroleum system}

Based on the distribution of effective source rocks in the Taoudeni Basin, combined with the structure characteristics of the basin and the distribution characteristic of the reservoir beds (Bai and Zheng, 2007), two petroleum systems are recognized in the basin. One is the infra-Cambrian petroleum system and the other is the Silurian petroleum system. They are illustrated in Fig. 7.

\subsection{Infra-Cambrian gas system}

In this system, source rocks are confined to the Middle and upper infra-Cambrian. They are widespread in the Taoudeni Basin and best developed in the Maqteir and Taoudeni depressions. Except the ramp regions, the source rocks are mature. The maximum Ro value is over $3.6 \%$ at the base of the middle infra-Cambrian and $2.6 \%$ at its top. The infra-Cambrian source rocks began to generate oil in the late infra-Cambrian and entered the peak of oil and gas generation in the Ordovician-Devonian. The source rocks became over mature by the end of the Carboniferous. The post-Hercynian uplifting halted hydrocarbon generation in the infra-Cambrian.

The oil and gas generated by the Middle and Upper Infra-Cambrian mudstones could accumulate in the same stratigraphic interval, the overlying strata or the underlying strata by vertical migration through faults or fractures. Oil and gas shows from this system were found throughout the infraCambrian. A tested gas flow was recorded from Abolag-1 well. The distribution of the system is shown in Fig. 8 .

The reservoir beds of the gas system are mainly composed of tight sandstones of the uppermost part of the lower infraCambrian, the middle infra-Cambrian carbonate rocks and the upper infra-Cambrian sandstones. The sandstone reservoir beds have a cumulative thickness of $200 \mathrm{~m}$ in the upper infra-Cambrian and the carbonate reservoir beds have a cumulative thickness of $190 \mathrm{~m}$ in the middle infra-Cambrian. The sandstone reservoir beds are dominated by shore zone quartzose sandstones. The carbonate reservoirs were composed of neritic and inter-tidal stromatolitic limestones. Numerous reservoir intervals occur in this system but their petrophysical properties vary greatly. Porosities fall in the range of $0-28 \%$.

Cambrian claystones constitute the regional seal for the system. They are widely distributed and have a good sealing capacity.

\begin{tabular}{c|c|c|c|c}
\hline & Source & Reservoir & Cap & Assemblage \\
\hline Carboniferous & & & & $\begin{array}{c}\text { Lower source \& upper } \\
\text { reservoir }\end{array}$ \\
\hline Devonian & & & & Upper source \& lower \\
& & & & reservoir \\
\hline Silurian & & & & Lower source \& upper \\
Ordovician & & & & $\begin{array}{r}\text { reservoir } \\
\hline \text { Cambrian }\end{array}$ \\
\cline { 3 - 5 } U. Infra-Cambrian & & & & In situ source and \\
reservoir
\end{tabular}

Fig.6 Types of source-reservoir-cap rock assemblage 


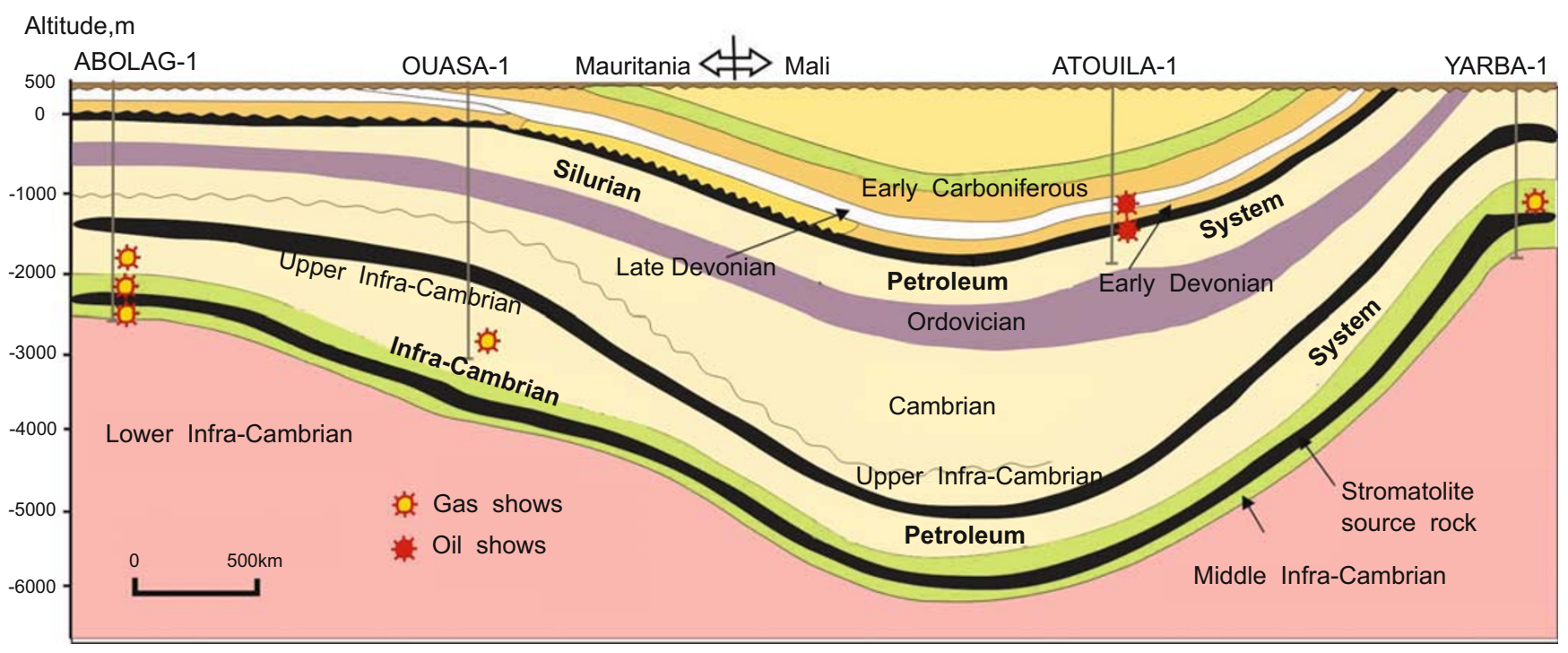

Fig. 7 Cross-section showing source rocks and oil/gas shows

\subsection{Silurian petroleum system}

This system includes the Ordovician, Silurian and Devonian. The Silurian was deposited in an extensive area, larger than the current Taoudeni Basin. The Silurian claystone probably was present originally within the entire basin. But subsequent uplifting and erosion led to the preservation of the Silurian source rocks only in the Taoudeni depression, which evolved into the present source kitchen center. The Silurian source rock is composed of black or dark gray mudstones.

Compared with the infra-Cambrian gas system, the distribution of the Silurian petroleum system is very limited (Fig. 9). The source rock is mainly located in the Taoudeni depression. Outside the depression, source rocks are very thin and their maturity is low so that they contributed little to the Silurian petroleum system in the basin.
The reservoirs of the system are the Ordovician sandstones and the basal Devonian sandstones. The diagenesis of these two sets of sandstone reservoir beds is weak so that their petrophysical properties are good. They are generally moderate to good reservoir beds. Hydrocarbon shows have been found in these sandstones. The Ordovician reservoir beds have a thickness of $500 \mathrm{~m}$. Porosities generally fall in the range of $7 \%-10 \%$ and some can reach as high as $18 \%-22 \%$. Permeability is $0.2-1 \mathrm{md}$. The basal Devonian sandstones are medium grained. Their average porosity is $10 \%$ and their thickness is approximately $50 \mathrm{~m}$.

The Silurian mudstone and the mudstone in the upper part of the Middle Devonian constitute the cap rock of the petroleum system. The cap rocks are thick and have a good sealing ability. The Silurian mudstone is the cap rock of

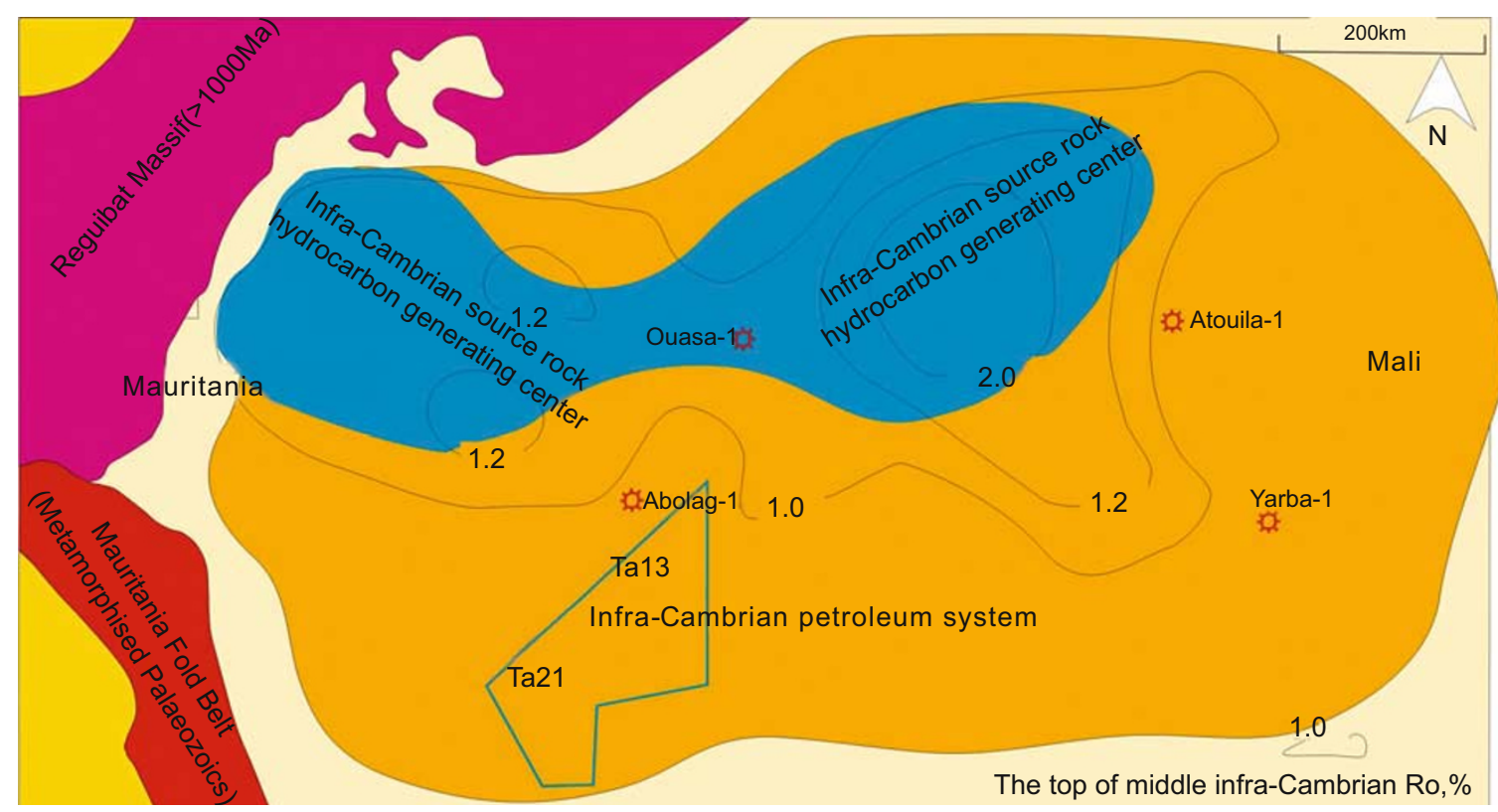

Fig. 8 Distribution of infra-Cambrian gas system in Taoudeni Basin 


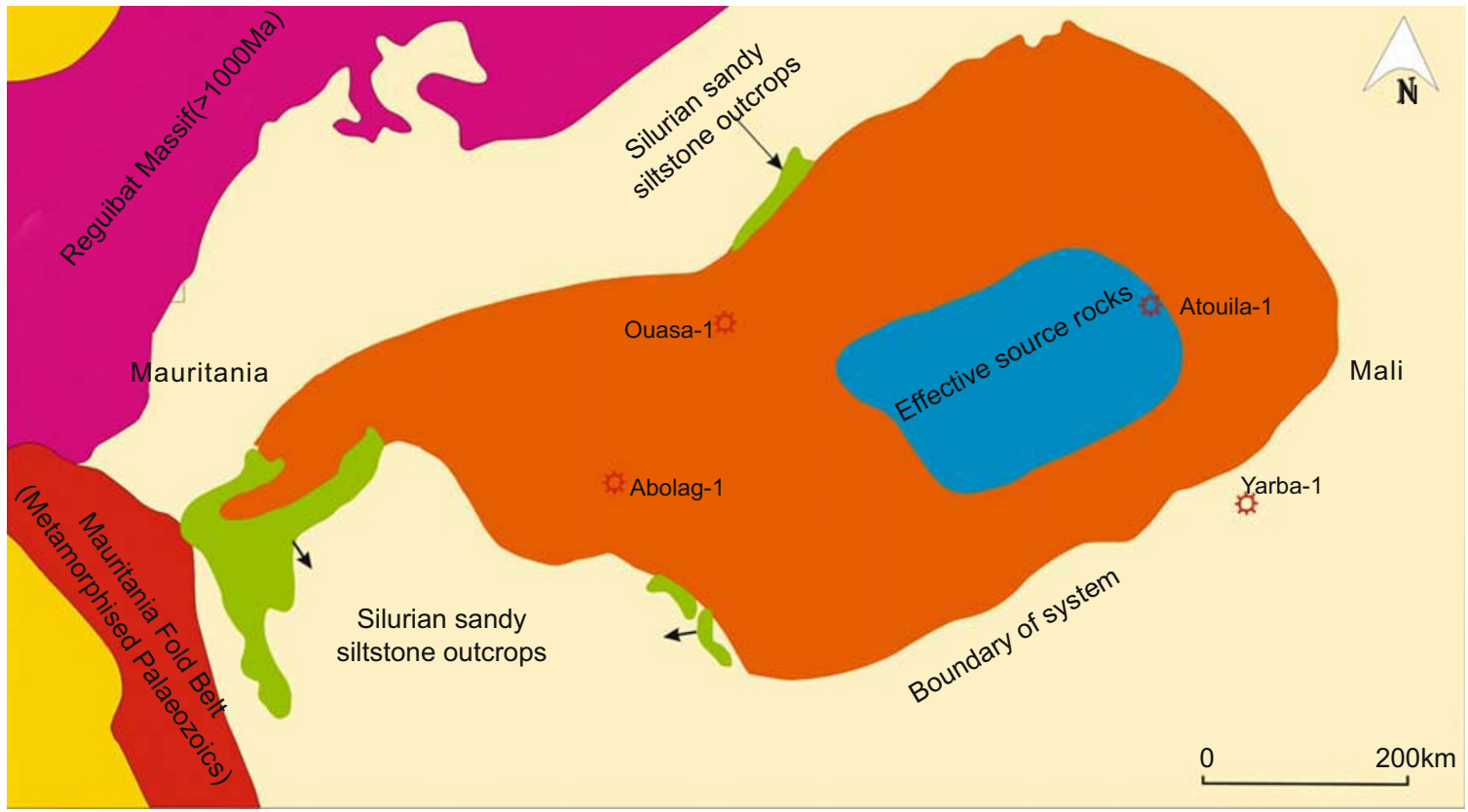

Fig. 9 Distribution of the Silurian petroleum system in Taoudeni Basin

the Ordovician sandstone reservoir beds and the Devonian mudstone the cap rock of the basal Devonian sandstone reservoir beds.

The timing of hydrocarbon migration and accumulation is in the Carboniferous. Like the infra-Cambrian gas system, uplifting and denudation at the end of the Carboniferous led to the destruction of most accumulations. As source rocks lost the ability of hydrocarbon generation, the accumulations are regarded as relic ones. Therefore, the Silurian petroleum system is also considered as a relict one and favorable sealing conditions are required for preservation of earlier formed petroleum accumulations.

\section{Integrated analyses of the main controls on the types of hydrocarbon accumulations}

Based on the above discussions, the features of hydrocarbon accumulation can be summarized as follows:

\subsection{Structural uplift and timing of petroleum generation controlled the timing of petroleum charging and preservation of hydrocarbon accumulations}

The Taoudeni Basin suffered post-Hercynian erosion at the end of the Carboniferous period. Then the basin experienced limited deposition during the Cretaceous period. The source rocks in the basin were not buried again to a much deeper depth to be able to generate hydrocarbons for the second time. Therefore, hydrocarbon generation took place fairly early. The late Carboniferous is the latest time for hydrocarbon generation. The subsequent gas supply was unable to compensate the hydrocarbon loss resulting from the post-Carboniferous diffusion. For the infra-Cambrian petroleum system, source rocks are highly mature to over mature. They were in the gas window by the Carboniferous time so that the generated gas could not be preserved in large quantities since that time (Fig. 10).

\subsection{Maturity, evolution history, and distribution of effective source rocks controlled hydrocarbon richness}

The amount of gas generation by infra-Cambrian source rocks is very limited after the Carboniferous. The distribution of the Infra-Cambrian source rocks controlled the distribution of natural gas. The long period of uplifting led to the destruction of the accumulated oil and thus only a small proportion of the originally generated gas could be preserved.

Silurian source rocks have a lower maturity than InfraCambrian source rocks. They generated a larger proportion of liquid hydrocarbons. Although hydrocarbon generation was halted early, oil was more easily preserved than gas. Thus, the Silurian petroleum system controlled the generation and distribution of oil.

\subsection{The main controls and geological processes controlled the type of petroleum accumulations}

The generation time of hydrocarbon and processes of petroleum presentation controlled the concentration of natural gas (Huang et al, 1996a and 1996b; Li et al, 2007; Dai, 1985; Dai et al, 2007; 2003; Zhao et al, 2005). Petroleum accumulations in the Infra-Cambrian petroleum system are dominated by relic gas accumulations. Gases in the stratigraphic and lithologic traps tend to be more easily preserved. These gas traps are mainly distributed within the depression or on the slopes of the depressions, but their sizes are small. Petroleum accumulations in the Silurian petroleum system, which covers a small area, are dominated by relic oil and gas accumulations.

In summary, lacking a thick Mesozoic sedimentary cover means that the hydrocarbon prospect would probably be 


\begin{tabular}{|c|c|c|c|c|c|c|c|c|c|c|c|c|c|c|}
\hline Basin & Stratum & \multicolumn{13}{|c|}{ Hydrocarbon generation history } \\
\hline \multirow{3}{*}{$\begin{array}{c}\text { Taoudeni } \\
\text { Basin }\end{array}$} & Silurian & & & & & & & & & & & & & \\
\hline & \multirow{2}{*}{$\begin{array}{l}\text { M-infra- } \\
\text { Cambrian }\end{array}$} & & & & & & & & & & & & & \\
\hline & & & & & & & & & & & & & & \\
\hline \multicolumn{2}{|c|}{ Stratum age } & L-infra & M-infra & U-infra & C & $\mathrm{O}$ & S & D & C & $\mathrm{P}$ & $\mathrm{T}$ & $J$ & K & $E$ \\
\hline \multicolumn{2}{|c|}{ Legend } & \multicolumn{2}{|c|}{ Oil generation } & \multicolumn{3}{|c|}{ Gas generation } & \multicolumn{8}{|c|}{ Dispersed time } \\
\hline
\end{tabular}

Fig. 10 Hydrocarbon-generation history and loss of oil and gas in Taoudeni Basin

moderate in the Taoudeni Basin.

\section{Conclusions}

Two petroleum systems: infra-Cambrian and Silurian systems, are identified in the Taoudeni Basin. The petroleum accumulations in the infra-Cambrian petroleum system are dominated by relic gas accumulations and those in the Silurian petroleum system by relic oil and gas accumulations. The Silurian petroleum system has a better exploration potential than the infra-Cambrian petroleum system. For the infra-Cambrian petroleum system, the favorable exploration area is around the source kitchen area. The favorable exploration area for the Silurian petroleum system lies in the eastern part of the basin.

\section{References}

Bai G P and Zheng L. Paleozoic composite petroleum system of north Africa: hydrocarbon distribution and main Controlling factors. Petroleum Science. 2007. 4(1): 21-29

Chen S P, Wang Y and Jin Z J. Controls of tectonics on both sedimentary sequences and petroleum systems in Tarim Basin, Northwest China. Petroleum Science. 2007. 4(2): 1-9

Dai J X. Coal-formed gas in west Siberian basin and its controlling accumulation rules. Natural Gas Geosciences. 1985. 5(1): 4-11 (in Chinese)

Dai J X, Wei Y Z and Zhao J Z. Important role of the formation of gas accumulations in the late stage in the formation of large gas fields. Chinese Geology. 2003. 30(1): 10-19 (in Chinese)

Dai J X, Zou C N, Tao S Z, et al. Formation conditions and main controlling factors of large gas fields in China. Natural Gas Geosciences. 2007. 18(4): 473-484 (in Chinese)
Huang Z L, Gao Y B and Hao S S. Quantitative evaluation and application of concentration seal of caprock. Acta Sedimentologica Sinica. 1996a. 14(2): 89-94 (in Chinese)

Huang Z L, Hao S S and Yang J Q. The dynamic equilibrium study on natural gas migration and accumulation in Pingluoba Field of West Sichuan. Natural Gas Geosciences. 1996b. 16(2): 9-11 (in Chinese)

Li J, Huang Z L and Wang H. Control of the time effect of hydrocarbon generation on distribution of oil and gas: Taking Lishu fault depression in southeastern uplifted area, the southern Songliao Basin, as an example. Natural Gas Geosciences. 2007. 26(9): 14-16 (in Chinese)

Macgregor D S. Giant fields, petroleum systems and exploration maturity of Algeria. in Macgregor D S, Moody R T J and Clark-Lowes D D (eds.), Petroleum geology of North Africa: Geological Society, London. 1998. Special Publication 132: 79-96

Makhous M, Galushkin Y and Lopatin N. Burial history and kinetic modeling for hydrocarbon generation, part II, Applying the GALO model to Saharan basins. American Association of Petroleum Geologists Bulletin. 1997. 81(10): 1679-1699

Mann P, Gahagan L and Gordon M B. Tectonic setting of the world's giant oil and gas fields. In Halbouty M T (ed.), Giant oil and gas fields of the decade 1990-1999. AAPG Memoir 78. Tulsa: AAPG. 2003: $15-105$

Tong X G and Guan Z Y. Atlas of Petroleum Exploration and Exploitation of the World (Africa Monograph). Beijing: Petroleum Industry Press. 2002 (in Chinese)

USGS. U.S. Geological Survey World Petroleum Assessment 2000-Description and Results. USGS Digital Data Series. 2000. DDS-60

Zhao W Z, Wang Z Y, Wang Z C, et al. Concept, Connotation and evaluation index of high effective gas source kitchen and its action to the formation of high effective gas pool. Acta Sedimentologica Sinica. 2005. 23(4): 709-718 (in Chinese)

(Edited by Yang Lei) 